\title{
Journalism in COVID-19 Web: Assessing the Gains, Pains, and Perils of Nigerian Journalists in Coronavirus Containment
}

\author{
Chijioke Odii ${ }^{1}$, Kelechi Johnmary Ani ${ }^{2, *}$ and Victor Ojakorotu ${ }^{3}$ \\ ${ }^{1}$ Department of Mass Communication, Renaissance University Ugbawka, Enugu State, Nigeria \\ ${ }^{2}$ Department of History and Strategic Studies, Alex Ekwueme Federal University Ndufu-Alike, Ebonyi State, \\ Nigeria \\ ${ }^{3}$ Department of Politics and International Relations and Deputy Director, School of Government Studies, \\ North West University, South Africa
}

\begin{abstract}
The study evaluated the effect of COVID-19 and the containment measures on Nigerian journalists and journalism practice in Nigeria. The study adopted the descriptive survey research design, with a questionnaire and personal interviews as instruments for data collection. A total of 362 copies of the questionnaire were correctly completed and returned by the respondents, and 25 editors and management staff of selected media organizations in Nigeria were interviewed for the study. The study's findings indicated that Nigerian journalists were actively involved in COVID-19 containment efforts in the country and that COVID-19 containment measures negatively affected journalists' performance and journalism practice in Nigeria. It is recommended, among others, that Personal Protective Equipment (PPE) should be provided for a journalist covering the pandemic, and journalists' fundamental human rights should be respected in COVID-19 containment efforts.
\end{abstract}

Keywords: Journalists, Nigeria, COVID-19, Coronavirus, journalism.

\section{INTRODUCTION}

COVID-19 has posed an existential threat to humanity since its outbreak in Wuhan, China, in December 2019, given the unprecedented rapidity of its spread and high mortality rate. The World Health Organization unsurprisingly declared the novel Coronavirus disease a global pandemic on $11^{\text {th }}$ March 2020 [1]. As at $29^{\text {th }}$ June, $2020,10,328,725$ confirmed cases, 505,983 deaths, 5,602,438 discharged cases and 4,220,304 active cases of COVID-19 had been recorded across affected countries [2]. Nigeria recorded its index case of Coronavirus in February 2020 and has, since then, recorded worrisome figures of confirmed cases of infections and deaths resulting from the pandemic. As of $29^{\text {th }}$ June $2020,132,304$ samples were tested; 24,567 confirmed cases, 14,995 active cases, 9,007 discharged cases, and 565 deaths from COVID-19 had been recorded in Nigeria [3]. Of the 36 states in Nigeria, confirmed cases of COVID-19 had been reported in 35 states and the Federal Capital Territory, Abuja. Cross River State is the only state without a confirmed case of COVID-19.

Journalists across the globe have numbered among the frontline workers in the tasking fight against coronavirus. As conveyors of information, journalists painstakingly perform their information provision,

*Address correspondence to this author at the Department of History and Strategic Studies, Alex Ekwueme Federal University Ndufu-Alike, Ebonyi State, Nigeria; Tel: +2348061552284; E-mail: kani4christ@gmail.com,

kelechi.ani@funai.edu.ng awareness creation, investigation, interpretation, sensitization, surveillance, and correlation functions, even in emergency situations. The undertakings are usually not without prices, prizes, lessons, and lapses.

Countries have taken varying drastic measures to contain the COVID-19 pandemic, including partial lockdown, total lockdown, closure of borders, schools, markets, offices, and worship centers, social distancing, and compulsory use of face masks in public places. These containment measures have had differing effects on various groups, including journalists. This study evaluated the gains, pains, and perils of Nigerian journalists in COVID-19 containment.

\section{Research Questions}

The following research questions were posed to guide the study:

1. To what extent are Nigerian journalists involved in the fight against the Coronavirus pandemic?

2. What hindrances do Nigerian journalists encounter in the fight against the COVID-19 pandemic?

3. What are the effects of COVID-19 containment measures on journalism practice in Nigeria?

\section{Research Design}

A descriptive survey design was adopted in the study. The essence was to elicit authentic responses 
from the Nigerian journalists, most of whom were involved in COVID-19 containment in the country, with first-hand or shared experiences of the gains and pains of the processes.

The questionnaire and personal interviews were the instruments for data collection in the study. The questionnaire contained open-ended and closed-ended questions. The open-ended questions were tailored to allow the respondents freedom and space to express their views, while the close-ended questions were designed to pin the respondents down to specific sets of responses to choose from to ensure exactitude and maintain the focus of the study. Some copies of the questionnaire were administered directly (offline) to selected journalists within the researcher's state of residence, while some copies were administered online to selected journalists outside the researcher's state of residence, through WhatsApp and Emails, due to lockdown and closure of inter-state borders in the country. Some of the interviews were conducted faceto-face, while some were conducted on the telephone. The interviews were used to elicit responses from editors and managers of media organizations in Nigeria.

\section{LITERATURE REVIEW}

Researchers have highlighted the severity of COVID-19 on all continents of the world. Gennaro, Pizzol, Marotta, Antunes, Racalbuto, Veronese, and Smith stated that the COVID-19 outbreak is proving to be an unprecedented disaster, especially in the most afflicted countries, including China, Italy, Iran, and the USA in all aspects, especially health, social and economic [4].

In their study on early transmission dynamics of Novel Coronavirus in Nigeria, Adegboye, Adekunle, and Gayawan noted that after the first case of COVID19 was detected in Nigeria on 27th February 2020, and the pandemic trajectory was slow compared with other countries [5]. They attributed the slow trajectory to early implementation of public health interventions measures like international travel ban imposed on 15 countries considered to be high risks countries, on 20th March 2020 followed by a total ban of all international flights in and out of the country; early closure of all schools, universities and worship centers throughout the country and restriction on movements within and outside major cities, which were all enforced from 29th March 2020. They also observed that there were several reasons for the late importations of COVID-19 to Africa, other than the speculations that the disease may not be viable in temperate regions. One of the reasons is limited international travel.

Journalists and the mass media have always featured prominently in emergency response and risk communication, including public health emergencies like the COVID-19 pandemic. Scanlon noted that "when disaster strikes, the media learn about it, report what they hear, try to obtain more information, use their files to add background to their stories, and dispatch news crews" [6]. According to him,

The media can clearly be a major asset before, during, and after emergencies. They are crucial, in fact, for the effective warning, for warnings must come from all possible channels at the same time. They are often the main way those in an impacted community learn what is happening, especially if they are forced to leave their homes. They are the single best way to get out public information to a mass audience and can be crucial if rumors are to be stopped. Yet, they are also the main purveyors of disaster myths because they focus on emergency agencies and officials and ignore the role played by individuals. Yet, in most destructive incidents, the initial response is by individuals and not by emergency personnel. Scanlon [6]

In line with the foregoing, Quarantelli [7] argued:

So, where do people get their images of disastrous phenomena if they do not base them on personal experiences? Some of the pictures they have undoubtedly come from deeply rooted cultural beliefs. But we think a strong case can be made that what average citizens and officials expect about disasters, what they come to know on ongoing disasters, and what they learned from disasters that have occurred are primarily not exclusively learned from mass media accounts. p. 2

Since the outbreak of Coronavirus Disease (COVID$19)$, especially since it was declared a global pandemic by the World Health Organization in March 2020, research findings and investigative reports have pointed to the negative effects of the pandemic and 
countries' containment measures on journalists and media organizations. In a survey conducted by the International Federation of Journalists - IFJ- [8] on COVID-19 and press freedom, $65.4 \%$ of the respondents stated that their pay, job security and/or working conditions had been negatively affected by the outbreak of the COVID-19 pandemic; $73.9 \%$ of them stated that their jobs as journalists had suffered more restrictions since the COVID-19 pandemic; $6.93 \%$ said they lost their jobs; $37.69 \%$ reported that they lost revenue/income; $35.70 \%$ said they changed topics they covered; $23.74 \%$ reported they lacked equipment to protect themselves in the field; $27.47 \%$ reported lack of equipment to work from home; $43.41 \%$ reported change in working patterns; $9.62 \%$ reported increased inequalities in newsrooms; $59.19 \%$ reported increased anxiety and stress; $16.38 \%$ reported legal restrictions on doing their jobs; $5.81 \%$ stated that their media organizations closed; $1.99 \%$ stated that they faced lawsuits for reporting on COVID-19; $1.91 \%$ said they got arrested for reporting on COVID-19; $2.95 \%$ said they got assaulted for reporting on COVID; $23.92 \%$ said they had difficulties in finding independent sources; and $6.41 \%$ of the respondents stated that nothing changed.

According to Human Rights Watch [9], "a rightsrespecting response to COVID-19 needs to ensure that accurate and up-to-date information about the virus, access to services, service disruptions, and other aspects of the response to the outbreak is readily available and accessible to all." It, however, observed that governments in a number of countries "have failed to uphold the right to freedom of expression, taking actions against journalists and healthcare workers. This ultimately limited effective communication about the onset of the disease and undermined trust in government action.

Nigerian journalists have had their own share of the negative consequence of COVID-19 containment measures. The International Press Institute - IPI- [10] reported that a law in the Nigerian state of Ebonyi passed earlier this month to penalize the spread of misinformation about COVID-19 and other infectious diseases were used to arrest and charge journalist Chijioke Agwu. The reporter, a correspondent for The Sun newspapers, was detained on the orders of Ebonyi State Governor David Umahi over a report he wrote about the Lassa fever, a viral illness endemic in parts of West Africa, including Nigeria. The governor accused Agwu of lying and breaking the new law - an allegation refuted by his employer.
The International Press Institute - IPI- [10] also reported that officials of the Delta State Task Force on Environment attacked Michael Ikeogwu, chairman of the Nigeria Union of Journalists (NUJ), and Mathew Omonighoe, correspondent of the Daily Post, as they were covering the COVID-19 lockdown. The two journalists were in the Uvwie Local Government Area of the state to monitor the stay-at-home order by the government when they were stopped by the task force officials and assaulted. Omonighoe reportedly had his Nikon D3100 camera destroyed.

Journalists in some other countries have equally encountered similar challenges in the fight against COVID-19. IFEX [11] reported that the spread of the coronavirus across the African continent correlates with an increase in incidents of intimidation and attacks on the media covering the pandemic. Beyond the frightening human toll, the COVID-19 is exacting across the world, and the pandemic has also led to attacks, detention, and judicial penalties against journalists covering the outbreak and related issues in various countries in West Africa. According to Accessnow [12], in Kenya, as the number of confirmed cases increased, so did the government's attempts to control access to information, noting that authorities established a dusk-to-dawn curfew, and two hours before the curfew was scheduled to start, law enforcement officers in Mombasa were filmed harassing and using physical force against journalists and others. According to Accessnow, there have been reports of at least two extrajudicial killings by law enforcement in their attempt to enforce the curfew, one of a 13-year-old boy and another of a motorbike driver. Accessnow [12] cautioned that "emergency situations must not serve as an excuse to harm journalism and undermine free expression. Journalism - including citizen journalism - plays a key role in holding government authorities and companies accountable in times of crisis."

Committee to Protect Journalists [13] identified global threats to press freedom in COVID-19 containment to include:

Arrests, threats, and harassment ("Fake news," disturbing public order arrests, harassment by the government, state authorities/proxies, public harassment, and anti-foreigner sentiment)

Restrictions on Access (Restrictions on journalist movement, reductions in press conferences, official access, FOIA suspension, and internet restrictions, shutdowns) 
Content restrictions and moderation (Suspension of media licenses, removal of content from internet platforms, move to the automation of moderation on platforms

Surveillance (New powers without sufficient oversight, restrictions, or limitations, creating a capability that creates a precedent, aggregate vs. individualized; anonymized)

In the same vein, UNESCO [14] observed some restrictions linked to the pandemic are limiting people's right to access information and the media's ability to fight against falsehoods. Threats here include:

- $\quad$ Freedom of expression and press freedom have been limited through laws proposed to counter disinformation or 'fake news'. Such laws have put journalists at criminal risk - often simply for raising criticisms or reflecting policy debates.

- The right to access information has been strained due to suspension in some cases of the public right to request information. The right is the other side of the coin to press freedom. It highlights the importance of governments making maximum information available. Access to the internet is equally important, whereas there is little relief from pre-existing disruptions in several countries.

- ntrusions on privacy through enhanced surveillance (often related to contact tracing and enforcing quarantines) are sometimes disproportionate and also risk being continued (and abused for other purposes) long after the pandemic.

The related literature reviewed in the study indicated that journalists and the mass media are relevant in COVID-19 containment, but they have been negatively affected by the pandemic and countries' containment measures.

\section{Theoretical Framework}

This study is anchored on the social responsibility theory. The social responsibility theory originated from the 1947 Hutchins commission on press freedom in the United States of America. It underscores the need for the press to display a sense of responsibility in exercising its freedom. Hutchins commission identified key journalistic standards the responsible press should maintain: "provide a full, truthful, comprehensive and intelligent account of the day's events in a context which gives them meaning,"

"serve as a forum for the exchange of comment and criticism,"

act as "a common carrier of the public expression,"

and give "a representative picture of constituent groups in society" [15].

In the social responsibility theory, the press enjoys the freedom to operate, but freedom has limits; it is guarded against abuse. This is where the social responsibility theory differs from libertarian theory. Ojobor [16] writes that "the libertarian era afforded the press so much unrestricted freedom that it became careless and irresponsible, thereby taking its freedom for granted." On the contrary, "social responsibility theory believes that freedom carries a concomitant obligation. In it, the press is to be responsible to society by carrying out certain essential functions of mass communication" [16]. The theory is appropriate for the study because it emphasizes press freedom coupled with social responsibility, especially in emergencies like the COVID-19 pandemic.

\section{Data Presentation and Analysis}

A total of 362 copies of the questionnaire were correctly completed and returned by the respondents. A total of 25 editors and management staff of media organizations in Nigeria were interviewed for the study. Out of the 362 respondents that completed the questionnaire, 194 were male while 168 were female. All the respondents $(100 \%)$ stated that Nigerian journalists were involved in the fight against coronavirus. Most of the respondents that completed the questionnaire, 346 (), noted that they had been involved in covering and reporting the COVID-19 pandemic; 16 () of them stated that they had not been involved in covering the pandemic. The 25 interviewees equally stated that they had been involved in covering and coordinating the coverage of the pandemic for their media organizations. These findings indicate that Nigerian journalists and managers of media organizations in Nigeria had been actively involved in the fight against the coronavirus pandemic in the country. The findings seem to provide justification for the claim that journalists are among the frontline workers in COVID-19 containment. One of the interviewees stated: 
Journalists are, indeed, among the frontline workers in the fight against the coronavirus pandemic. Just like in other crisis and emergency situations, the Nigerian journalists have been at the forefront in the fight against coronavirus. You must have observed that media organizations in Nigerian send their reporters to cover the daily media briefing of the Presidential Taskforce on COVID19. The media organizations also cover the activities of the taskforce in different states of the country and other developments relating to the pandemic. The Nigerian media have been very busy since the index case of the coronavirus was reported in Nigeria (KI-5, 2020).

One of the items in the questionnaire was used to determine the specific roles Nigerian journalists had played in the containment of COVID-19 in the country. The respondents identified the role of Nigerian journalists in the fight against COVID-19, as presented in Table 1 below.

From Table 1 below, the respondents identified provision of information (29\%), creation of awareness $(23.2 \%)$, sensitization of the public $(17.1 \%)$, investigation of reports and claims $(12.4 \%)$, and interpretation of information and reports $(18.2 \%)$ as the role Nigerian journalists had played in the fight against COVID-19 in the country. These roles were also identified by the interviewees as the functions of Nigerian journalists in the fight against COVID-19. One of the interviewees stated:

Nigerian journalists have been very much alive to their social responsibilities in the fight against COVID-19. Nigerian journalists have worked hard to provide authentic information to counter the unverified rumors and misinformation circulated on the social media platforms about COVID-19. Everybody in Nigeria now turns to the mass media to get correct information about COVID-19 (KI-03, 2020).

Another interviewee stated:

Nigerian journalists have played key roles in sensitizing the public and creating awareness about coronavirus and the preventive measures prescribed by the government. You can recall that there were conspiracy theories making many Nigerians not to believe the existence of coronavirus in the country. Through sensitization and awareness creation, Nigerian journalists have changed the attitude and perception of some of the Nigerians who initially did not believe in the existence of Coronavirus (KI-09, 2020).

The respondents were asked to rate the extent of involvement of Nigerian journalists in the fight against COVID-19 in the country. The data displayed in Table 2 below indicate that a majority of the respondents, 276 $(76.2 \%)$ and $46(12.7 \%)$, rated the level of involvement of Nigerian journalists in COVID-19 containment 'Very High' and 'High,' respectively.

Most of the respondents believed that Nigerian journalists encountered hindrances in the fight against COVID-19. Table 3 below shows that $253(69.9 \%)$ and $91(25.1 \%)$ of the respondents strongly agreed and agreed, respectively, that Nigerian journalists encountered hindrances in COVID-19 containment.

Table 1: Role of Nigerian Journalists in COVID-19 Containment

\begin{tabular}{|c|c|c|c|c|c|}
\hline & & Frequency & Percent & Valid Percent & Cumulative Percent \\
\hline \multirow[t]{6}{*}{ Valid } & Provision of Information & 105 & 29.0 & 29.0 & 29.0 \\
\hline & Creation of Awareness & 84 & 23.2 & 23.2 & 52.2 \\
\hline & Sensitization of the Public & 62 & 17.1 & 17.1 & 69.3 \\
\hline & Investigation of reports and claims & 45 & 12.4 & 12.4 & 81.8 \\
\hline & interpretation of Information and Reports & 66 & 18.2 & 18.2 & 100.0 \\
\hline & Total & 362 & 100.0 & 100.0 & \\
\hline
\end{tabular}


Table 2: Respondents' Rating of Level of Involvement of Nigerian Journalists in COVID-19 Containment

\begin{tabular}{|c|c|c|c|c|c|}
\hline \multicolumn{1}{|c|}{} & Frequency & Percent & Valid Percent & Cumulative Percent \\
\hline \hline \multirow{3}{*}{ Valid } & Very High & 276 & 76.2 & 76.2 & 76.2 \\
& High & 46 & 12.7 & 12.7 & 89.0 \\
\cline { 2 - 7 } & Undecided & 6 & 1.7 & 1.7 & 90.6 \\
\cline { 2 - 7 } & Low & 24 & 6.6 & 6.6 & 97.2 \\
& Very Low & 10 & 2.8 & 2.8 & 100.0 \\
\hline
\end{tabular}

Table 3: Respondents' Views on Whether Nigerian Journalists Encounter Hindrances in COVID-19 Containment

\begin{tabular}{|c|c|c|c|c|c|}
\hline \multicolumn{1}{|c|}{} & Frequency & Percent & Valid Percent & Cumulative Percent \\
\hline \hline \multirow{3}{*}{ Valid } & Strongly Agree & 253 & 69.9 & 69.9 & 69.9 \\
\cline { 2 - 6 } & Agree & 91 & 25.1 & 25.1 & 95.0 \\
\cline { 2 - 6 } & Undecided & 4 & 1.1 & 2.1 & 96.1 \\
\cline { 2 - 6 } & Disagree & 8 & 2.2 & 1.7 & 98.3 \\
& Strongly Disagree & 6 & 100.0 & 100.0 & \\
\hline
\end{tabular}

An open-ended item in the question was used to determine the hindrances Nigerian journalists encountered in the fight against COVID-19 in the country. The respondents identified the following hindrances that Nigerian journalists encountered in COVID-19 containment:

1. Pay cut - reduction of journalists' remunerations by their media organizations.

2. Job losses - Many journalists have been laid off by their media organizations.

3. Harassment of journalists by security operatives

4. Lack of transparency by government

5. Restriction of movement

6. Arrest of journalists

7. Banning journalists from government houses, offices, and events because of their reports on the government's handling of COVID-19 related issues.

8. Threats to journalists by government functionaries
9. Lack of welfare package for journalists covering COVID-19

10. Poor remuneration

11. Irregularly and delayed payment of entitlements

12. Risk of COVID-19 infection due to lack of Personal Protective Equipment (PPE)

13. Excessive workload resulting from the disengagement of some journalists by their media organizations.

All the respondents $(100 \%)$ stated that they were aware that some media organizations in Nigeria had laid off some journalists and that they were aware of some media organizations that cut the remunerations of journalists as a result of COVID-19. Also, 208 (\%) of the respondents stated that their media organizations laid off some journalists; 212 (\%) of them stated that their media organizations cut journalists remunerations, and 196 (\%) of them stated that their media organizations furloughed some journalists as a result of the Coronavirus pandemic.

Table 4 below shows that $282(77.9 \%)$ and 51 $(14.1 \%)$ of the respondents rated the effect of the 
Table 4: Respondents' Rating of Effect of the Hindrances on Nigerian Journalists' Performance in COVID-19 Containment

\begin{tabular}{|c|c|c|c|c|c|}
\hline \multicolumn{1}{|c|}{} & Frequency & Percent & Valid Percent & Cumulative Percent \\
\hline \hline \multirow{3}{*}{ Valid } & Very High & 282 & 77.9 & 77.9 & 77.9 \\
\cline { 2 - 6 } & High & 51 & 14.1 & 14.1 & 92.0 \\
& Undecided & 3 & .8 & .8 & 92.8 \\
\cline { 2 - 6 } & Low & 22 & 6.1 & 6.1 & 98.9 \\
\cline { 2 - 6 } & Very Low & 4 & 1.1 & 1.1 & 100.0 \\
\cline { 2 - 6 } & Total & 362 & 100.0 & 100.0 & \\
\hline
\end{tabular}

Table 5: Respondents' Views on Whether COVID-19 Containment Measure Stifle Journalism Practice in Nigeria

\begin{tabular}{|c|c|c|c|c|c|}
\hline \multicolumn{1}{|c|}{} & Frequency & Percent & Valid Percent & Cumulative Percent \\
\hline \hline \multirow{3}{*}{ Valid } & Strongly agree & 224 & 61.9 & 61.9 & 61.9 \\
\cline { 2 - 6 } & Agree & 89 & 24.6 & 24.6 & 86.5 \\
\cline { 2 - 6 } & Undecided & 14 & 3.9 & 3.9 & 90.3 \\
\cline { 2 - 6 } & Disagree & 18 & 5.0 & 5.0 & 95.3 \\
& Strongly Disagree & 17 & 4.7 & 4.7 & 100.0 \\
\hline
\end{tabular}

hindrances on the performance of Nigerian journalists in COVID-19 containment very high and high, respectively. This result supports the views expressed by most of the interviewees.

From Table 5 above, a majority of the respondents expressed the view that COVID-19 containment measures stifle journalism practice in Nigeria. The table indicates that $224(61.9 \%)$ and $89(24.6 \%)$ of the respondents strongly agreed and agreed, respectively, that COVID-19 containment measures stifle journalism practice in Nigeria.
The data displayed in Table 6 below show that most of the respondents believed that COVID-19 measures did not enhance journalism practice in Nigeria. From the table, $93(25.7 \%)$ and $220(60.8 \%)$ of the respondents disagreed and strongly disagreed, respectively, to the opinion that COVID-19 containment measures enhanced journalism practice in Nigeria.

The data displayed in Table 7 indicate that 284 $(78.5 \%)$ and $64(17.7 \%)$ of the respondents rated the effect of COVID-19 containment measures on

Table 6: Respondents' Views on Whether COVID-19 Containment Measure Enhance Journalism Practice in Nigeria

\begin{tabular}{|c|c|c|c|c|c|}
\hline & & Frequency & Percent & Valid Percent & Cumulative Percent \\
\hline \multirow[t]{6}{*}{ Valid } & Strongly Agree & 20 & 5.5 & 5.5 & 5.5 \\
\hline & Agree & 15 & 4.1 & 4.1 & 9.7 \\
\hline & Undecided & 14 & 3.9 & 3.9 & 13.5 \\
\hline & Disagree & 93 & 25.7 & 25.7 & 39.2 \\
\hline & Strongly Disagree & 220 & 60.8 & 60.8 & 100.0 \\
\hline & Total & 362 & 100.0 & 100.0 & \\
\hline
\end{tabular}


Table 7: Respondents' Rating of the Effect of COVID-19 Containment Measures on Journalism Practice in Nigeria

\begin{tabular}{|c|c|c|c|c|c|}
\hline \multicolumn{2}{|c|}{} & Frequency & Percent & Valid Percent & Cumulative Percent \\
\hline \hline \multirow{3}{*}{ Valid } & Very High & 284 & 78.5 & 78.5 & 78.5 \\
& High & 64 & 17.7 & 17.7 & 96.1 \\
\cline { 2 - 6 } & Undecided & 6 & 1.7 & 1.7 & 97.8 \\
\cline { 2 - 6 } & Low & 5 & 1.4 & 1.4 & 99.2 \\
& Very Low & 3 & .8 & .8 & 100.0 \\
& Total & 362 & 100.0 & 100.0 & \\
\hline
\end{tabular}

journalism practice in Nigeria very high and high, respectively.

\section{DISCUSSION OF RESULTS}

The findings of the study indicate that Nigerian journalists are involved in COVID-19 containment efforts in the country. Most of the respondents rated the involvement of Nigerian journalists in the fight against COVID-19 high. These findings are in consonance with the findings of Quarantelli (1991) and Scanlon (2007) that journalists (mass media) are key factors in the management of emergencies and disasters.

The study also found that Nigerian journalists and media organizations have encountered hindrances in the fight against the COVID-19 pandemic. Such hindrances include loss of jobs, pay cut, revenue loss, harassment by security operation, arrest and detention, furlough by media organizations, and lack of transparency by the government. A majority of the respondents stated that COVID-19 containment measures have negative effects on journalists' performance in the fight against COVID-19 and journalism practice in Nigeria. These findings are in line with the results of the survey by the International Federation of Journalists (2020) and investigative reports by Human Rights Watch (2020), International Press Institute, Accessnow (2020), and UNESCO (2020) cited in this study.

\section{CONCLUSION AND RECOMMENDATIONS}

Covid 19 has a lot of implications for the field of journalism. In Nigeria, a number of journalists who specialize in human security and health reportage spent their time investigating the changing nature of the pandemic from the index case to the level of community transmission. The study has shown that Nigerian journalists are among the frontline workers in
COVID-19 containment in the country. The findings of the study equally revealed that COVID-19 containment measures used by the Nigerian government negatively affected Nigerian journalists' performance in the fight against COVID-19 and, by extension, journalism practice in Nigeria.

These recommendations are made based on the findings of the study.

1. Personal Protective Equipment (PPE) should be provided for journalists covering COVID-19.

2. There is a need for transparency in the government's containment measures against COVID-19.

3. Government should give financial grants to private media organizations in Nigeria to help them retain their journalists and stop pay cuts.

4. Government and its agents should respect journalists' fundamental human rights in COVID19 containment.

5. Government should give incentives to journalists and media organizations covering COVID-19.

\section{REFERENCES}

[1] WHO WHO Director-General's opening remarks at the media briefing on COVID-19, 2020

[2] Worldometer https://www.worldometers.info 2020 Accessed on $20^{\text {th }}$ May 2020

[3] Nigeria Centre for Disease Control. https://covid19.ncdc.gov. ng 2020 Accessed on $29^{\text {th }}$ May 2020

[4] Gennaro FD, Pizzol D, Marotta C, Antunes M, Racalbuto V, Veronese N, Lee S. Coronavirus Diseases (COVID-19) current status and future perspectives: A narrative review. International Journal of Environmental Research and Public Health Review 2020.

[5] Adegboye OA, Adekunle Al, Gayawan E. Early Transmission Dynamics of Novel Coronavirus (COVID-19) in Nigeria. 
International Journal of Environmental Research and Public Health 2020; 1-10.

https://doi.org/10.3390/ijerph17093054

[6] Scanlon J. Unwelcome Irritant or Useful Ally? The Mass Media in Emergencies. In: Rodriguez H, Quarantelli EL, Dynes RR, (Eds.). Handbook of disaster research 2007. https://doi.org/10.1007/978-0-387-32353-4_24

[7] Quarantelli EL. Lessons From Research: Findings on Mass Communications System Behavior in the Pre, Trans and Postimpact Periods Newark: Disaster Research Center 1991.

[8] International Federation of Journalists. IFJ Survey on COVID-19 and press freedom. 2020 Retrieved on 22/6/2020 from https://www.ifj.org.user>user_upload. Accessed on $28^{\text {th }}$ May, 2020

[9] Human Rights Watch. Human rights dimensions of COVID19 response 2020. Retrieved from https://www.hrw.org/news/ 2020/03/19/human-rights-dimensions-covid-9-response. Accessed on $10^{\text {th }}$ May, 2020

[10] International Press Institute, Emergency COVID-19 measures must not be used to roll back on media freedom. 2020 Sourced on 25/6/2020 from https://ipi.media/ emergency-covid-19-measures-must-not-be-used-to-rollback-media-freedom/ Accessed on $17^{\text {th }}$ May, 2020
[11] IFEX. Authorities across West Africa attacking journalists covering COVID-19 Pandemic 2020. Retrieved on 23/6/2020 from https://ifex.org/authorities-across-west-africa-attackingjournalists-covering-covid-19-pandemic/ Accessed on $4^{\text {th }}$ May, 2020

[12] Accessnow. Fighting misinformation and defending free expression during COVID-19: Recommendations for states. Sourced on 27/6/2020 from https://www.accessnow.org/ covid19-data-proctection/ Accessed on $20^{\text {th }}$ May, 2020

[13] March 2020. Retrieved on 25/6/2020 from htts://www.who.int/dg/speeches/detail/who-director-generals-opening-remarks-at-the-media-briefing-on-covid-19-11march-2020. Accessed on $20^{\text {th }}$ May, 2020

[14] UNESCO (2020). Journalism, press freedom, and COVID-19. Retrieved on 23/6/2020 from https://en.unesco.org.default. files Accessed on $25^{\text {th }}$ May, 2020

[15] McQuail D. McQuail's mass communication theory $\left(5^{\text {th }}\right.$ edition). London: SAGE publications Ltd. 2005.

[16] Ojobor IJ. 'Mass communication theories,' in C.S. Okunna (ed) Teaching mass communication: A multi-dimensional approach. Enugu: New Generation Books 2002.

\section{https://doi.org/10.6000/2292-2598.2021.09.02.8}

(C) 2021 Odii et al.; Licensee Lifescience Global.

This is an open access article licensed under the terms of the Creative Commons Attribution Non-Commercial License (http://creativecommons.org/licenses/by-nc/3.0/) which permits unrestricted, non-commercial use, distribution and reproduction in any medium, provided the work is properly cited. 